\title{
ANALISIS SENTIMEN REVIEW PENJUALAN PRODUK UMKM PADA KABUPATEN NIAS DENGAN KOMPARASI ALGORITMA KLASIFIKASI MACHINE LEARNING
}

\author{
Mawaddah Harahap ${ }^{\bowtie}$, Bintang P. A. Sihombing, Olga A. F. Laia, Bryan T. Saragih, \\ Kuandi Dharma \\ Fakultas Teknologi dan Ilmu Komputer, Universitas Prima Indonesia, Medan, Indonesia \\ Email: mawaddah@unprimdn.ac.id
}

DOI: https://doi.org/10.46880/jmika.Vol5No2.pp147-154

\begin{abstract}
Changes in consumer habits in buying and shopping in the era of the covid-19 pandemic have a significant impact, especially on MSME products, but utilizing the sentiment analysis method, is expected to help increase sales. The purpose of the study was to determine how consumers respond to the purchase of MSME products in the NIAS district. The MSME products typical of Nias district which are marketed through social media are grouped into four categories, namely handicraft products, food products, antiques, and musical instrument products. The way this method works is to group datasets in customer comments on Facebook and Instagram, then processed using a comparison machine learning classification algorithm consisting of Support Vector Machine (SVM), Naïve Bayes (NB), K-Nearest Neighbor (KNN), and Artificial Neural Network (ANN) to produce the desired output to increase MSME sales during the Covid-19 period. The source of the dataset is obtained from the sale of MSME products from social media, namely Facebook and Instagram, based on customer comments, training, and testing is carried out based on the dataset through the stages of text pre-processing, feature extraction, 10 folds CrossValidation and evaluation. The results obtained based on the comparison results of the Machine Learning algorithm are that the Under Are Curve (UAC) value in the ANN method is smaller at 0.417 and the SVM method is higher at 0.988. In this case, through the SVM algorithm, more dataset testing can be carried out by adding more sales of MSME products on social media, so that more accurate results can be obtained.
\end{abstract}

Keyword: Support Vector Machine (SVM), Nä̈ve Bayes, K-Nearest Neighbor (KNN), Artificial Neural Network, Covid-19.

\begin{abstract}
ABSTRAK
Perubahan kebiasaan konsumen dalam membeli dan berbelanja di era pandemi covid-19 berdampak signifikan khususnya pada produk UMKM, namun dengan memanfaatkan metode analisis sentimen diharapkan dapat membantu meningkatkan penjualan. Tujuan penelitian untuk mengetahui bagaimana respon konsumen terhadap pembelian produk UMKM di kabupaten NIAS. Produk UMKM khas kabupaten Nias yang dipasarkan melalui media sosial dikelompokkan menjadi empat kategori, yaitu produk kerajinan, produk makanan, barang antik, dan produk alat musik. Cara kerja metode ini adalah dengan mengelompokkan dataset pada komentar pelanggan di Facebook dan Instagram, kemudian diolah menggunakan algoritma klasifikasi machine learning perbandingan yang terdiri dari Support Vector Machine (SVM), Naïve Bayes (NB), K-Nearest Neighbor (KNN), dan Jaringan Syaraf Tiruan (JST) untuk menghasilkan output yang diinginkan untuk meningkatkan penjualan UMKM selama masa Covid-19. Sumber dataset diperoleh dari penjualan produk UMKM dari media sosial yaitu facebook dan instagram berdasarkan komentar pelanggan, pelatihan, dan pengujian yang dilakukan berdasarkan dataset melalui tahapan text pre-processing, ekstraksi fitur, 10 kali lipat Cross-Validasi dan evaluasi. Hasil yang diperoleh berdasarkan hasil perbandingan algoritma Machine Learning diperoleh nilai Under Are Curve (UAC) pada metode JST lebih kecil yaitu sebesar 0,417 dan pada metode SVM lebih tinggi yaitu sebesar 0,988. Dalam hal ini melalui algoritma SVM dapat dilakukan pengujian dataset lebih banyak dengan menambah lebih banyak penjualan produk UMKM di media sosial, sehingga dapat diperoleh hasil yang lebih akurat.
\end{abstract}

Kata Kunci: Support Vector Machine (SVM), Nä̈ve Bayes, K-Nearest Neighbor (KNN), Jaringan Syaraf Tiruan (JST), Covid-19. 


\section{PENDAHULUAN}

Wabah Virus Corona atau COVID-19 berdampak signifikan terhadap berbagai lini kehidupan, termasuk aktivitas ekonomi di Indonesia. Para pelaku Usaha Kecil Menengah (UKM) berupaya mengantisipasi penyebaran COVID-19 di lingkungan kerja dengan berbagai cara. Salah satunya, mengimbau karyawan untuk bekerja di rumah atau work from home (WFH) dan tak perlu datang ke kantor hal ini sesuai dengan kebijakan pemerintah dengan diberlakukan social distancing dan Pembatasan Sosial Berskala Besar (PSBB), namun perubahan prilaku konsumen memiliki dampak terhadap pelaku bisnis seperti UMKM yang mengalami penurunan penjualan khususnya UMKM yang masih menggunakan konsep penjualan offline. Untuk itu, pemerintah telah menerapkan (lima) program yang termasuk dalam paket kebijakan pemerintah untuk UMKM yaitu bantuan sosial (bansos), insentif perpajakan, relaksasi dan restrukturiasi kredit, perluasan pembiayaan dan mendorong pelaku bisnis UMKM melakukan inovasi pada market baru (Agustian, 2020; Santia, 2020), sedangkan pemerintah akan menerapkan pendekatan konsep marketplace.

Kabupaten Nias adalah salah satu pulau yang terletak di Provinsi Sumatera Utara yang terdiri dari empat kabupaten, yaitu: Kabupaten Nias, Kabupaten Nias Selatan, Kabupaten Nias Utara, dan Kabupaten Nias barat. Yang merupakan 62 daerah tertinggal yang ditetapkan pada 27 April 2020 oleh Presiden Joko Widodo (Admin Kabupaten Nias, 2020). Maka dari itu, penulis merasa tertarik untuk melakukan penelitian penjualan produk UMKM, agar dapat meningkatkan penjualan melalui media social berdasarkan analisis sentiment.

Analisis sentiment adalah penggunaan pemrosesan bahasa alami, analisis teks, linguistik komputasi, dan biometrik untuk mengidentifikasi, mengekstrak, mengukur, dan mempelajari keadaan afektif dan informasi subjektif secara sistematis (Agustian, 2020). Metode ini berfungsi untuk memahami dan mengelompokkan emosi (positif, negatif, dan netral) yang terdapat dalam tulisan menggunakan teknik analisis teks, dan biasa terapkan pada platform online, seperti media sosial, ecommerce, dan website (Santia, 2020).

Perubahan kebiasan konsumen dalam membeli serta berbelanja diera pandemic memiliki dampak yang signifikan (Admin Dinas Kominfo Sumut, 2020), namun dengan memanfaatkan metode analisis sentiment diharapkan dapat membantu meningkatkan penjualan UMKM. Tujuan dari penelitian adalah untuk mengetahui bagaiman respon konsumen terhadap pembelian produk UMKM pada kabupaten NIAS. Karena cara kerja metode ini adalah mengelompokkan data yang ada lalu diproses hingga menghasilkan output yang diinginkan guna menunjuang UMKM dimasa Covid-19.

Sebuah review barang berguna untuk melihat bagaimana umpan balik pembeli sebelumnya melalui sebuah komentar positif atau negatif. Komentar pengguna mengekspresikan pendapat mereka tentang kualitas, harga, layanan dan kecepatan pengiriman. Pengguna belanja online sering menggunakan komentar dari pengguna sebelumnya ketika mereka akan melakukan pembelian barang (Chen, 2012), pengelompokan review barang dari konsumen dipengaruhi oleh emosi (sentimen) yang dikelompokkan atau diklasifikasikan untuk menentukan kepolarisasiannya yaitu positif atau negatif (Indriati \& Ridok, 2016). Berbasis Long Short Term Memory (LSTM) untuk mengklasifikasikan opini produk UMKM dengan perbandingan model lain seperti Naïve Bayes, Support Vector Machine, KNearest Neighbor dan jaringan syaraf tiruan yang bersumber pada dataset hasil survey square dengan fokus pada pemahaman review produk yang diklasifikasikan untuk menghasilkan feedback positif atau negative (Yennimar, Rizal, Husein, \& Harahap, 2019).

Algoritma klasifikasi sentimen seperti Naïve Bayes (NB), Support Vector Machine (SVM), dan KNearest Neighbor (KNB), artificial neural network (ANN) banyak diusulkan peneliti karena dapat diterapkan diberbagai masalah seperti, rating program televisi (Saifinnuha, 2015), tingkat kepuasan pengguna penyedia layanan telekomunikasi seluler Indonesia (Rofiqoh, Perdana, \& Fauzi, 2017), tayangan televisi berdasarkan opini masyarakat (Nurjanah, Perdana, \& Fauzi, 2017), topik berita (Siringoringo, Jamaluddin, \& Perangin-Angin, 2020), opini produk (Hanggara, Akhriza, \& Husni, 2017), review barang (Haryanto, Muflikhah, \& Fauzi, 2018), penilaian pelayanan situs belanja online (Muljono, Artanti, Syukur, \& Prihandono, 2018), tinjauan penjualan pasar (Lutfi, Permanasari, \& Fauziati, 2018), travel agen (Ernawati \& Wati, 2018), dan review hotel (Taufik, 2018).

\section{METODE PENELITIAN}

\section{Jenis Penelitian}

Penilitian ini menggunakan jenis penilitian verifikasi dan eksperimen dengan tujuan untuk menciptakan pengetahuan baru dari teori" yang sudah ada. Kerangka konseptual merupakan kerangka 
berpikir mengenai hubungan antar variabel" yang terlibat dalam penilitian atauhubungan antar konsep dengan konsep lainnya dari masalah yang diteliti sesuai dengan apa yang telah diuraikan pada studi kepustakaan. Konsep dalam hal ini adalah suatu abtraksi atau gambaran yang dibangun dengan mengeneralisasikan suatu penilitian oleh karena itu konsep tidak dapat diamati dan diukur secara langsung.

Pada tahap ini dilakukan pengumpulan data penjualan produk UMKM pada media social yaitu Facebook dan Instagam yang berasal dari daerah kabupaten Nias, Kabupaten Nias Utara, Kabupaten Nias Selatan, dan Kabupaten Nias Barat. Adapun produk UMKM khas kabupaten Nias yang dipasarkan melalui media social dikelompokkan kedalam empat kategori, yaitu produk kerajinan tangan, produk makanan, barang antik dan produk alat musik.

Melalui analisi Berdasarakan penjualan produk UMKM yang dilakukan pada media sosialCara kerja metode ini adalah mengelompokkan data yang ada pada komentar pelanggan pada Media Sosial, lalu diproses menggunakan komparasi algoritma Klasifikasi Machine Learning yang terdiri dari Support Vector Machine (SVM), Naïve Bayes (NB), K-Nearsrt Neighbor (KNN) dan Artificial Neural Network (ANN) hingga menghasilkan output yang diinginkan guna menigkatkan penjualan UMKM dimasa Covid-19. Sumber dataset diperoleh dari penjulan produk UMKM dari media social yaitu facebook dan Instagram, berdasarkan komentar pelanggan tersebut dilakukan pelatihan dan pengujian berdasarkan dataset melalui tahapan text pre-pocessing, feature Extraction, 10 folds Cross Validation dan evaluasi.

\section{Prosedur Kerja}

Berikut ini adalah prosedur kerja yang dilakukan dalam penelitian:

1. Tahap persiapan.

Aktifitas penelitian dititikberatkan pada menentukan topik, identifikasi dan perumusan masalah, menentukan tujuan penelitian, menentukan batasan dan metodologi penelitian.

2. Studi Pustaka

Tahapan studi pustaka digunakan untuk mencari informasi referensi mengenai analisis sentimen, topik terkait objek penelitian, metode machine learning dan literatur terkait metode yang diusulkan.

3. Pengumpulan Data

Pada tahapan ini akan dilakukan proses pengumpulan data produk UMKM pada media sosial.
4. Tahapan Perancangan.

Pada tahap ini dilakukan perancangan Media sosail yang akan dijadikan sebagai media pemasaran dan promosi produk-produk UMKM.

5. Tahapan Analisis Sentimen, meliputi beberapa tahapan, yaitu

a. Tahapan Proses ambil data produk UMKM dari sumber komentar pelanggan pada media social: Instagram, Facebook.

b. Tahapan pre-processing terdiri dari beberapa tahapan yaitu:

1. Tokenize merupakan proses untuk memisahmisahkan kata. Potongan kata tersebut disebut dengan token atau term

2. Filter Token merupakan proses mengambil kata-kata penting dari hasil token.

3. Stem yaitu proses pengubahan bentuk kata menjadi kata dasar. Metode pengubahan bentuk kata menjadi kata dasar ini menyesuaikan struktur bahasa yang digunakan dalam proses stemming.

4. Filter stopwords adalah proses menghilangkan kata-kata yang sering muncul namun tidak memiliki pengaruh apapun dalam ekstraksi sentimen suatu review. Kata yang termasuk seperti kata penunjuk waktu, kata tanya.

c. Feature Extraction yaitu tahapan membuat pengklasifikasi lebih efisien dengan mengurangi jumlah data yang dianalisa, sedangkan pembobotan untuk mengetahui polaritas dari target opini tersebut (positif atau negatif). Selain itu, pemberian bobot terhadap target opini juga bertujuan untuk merangking fitur produk, sehingga dapat diketahui fitur produk apa yang paling disukai dan paling tidak disukai oleh customer

d. Analisa Algoritma Klasifikasi Machine Learning yaitu tahapan analisa metode yang digunakan untuk menganalisa akurasi hasil review produk algoritma klasifikasi machine learning yaitu metode Support Vector Machine (SVM).

6. Interprestasi Hasil merupakan tahapan evaluasi untuk menghitung nilai akurasi dan nilai Area Under Curve (AUC).

7. Tahap Implementasi dan Pengujian. Tahap ini dimaksudkan sebagai langkah pengujian kinerja program aplikasi.

8. Tahap penyelesaian. Tahap dimana catatan kegiatan dan hasil penelitian didokumentasikan. 


\section{Kerangka Metode Yang Diusulkan}

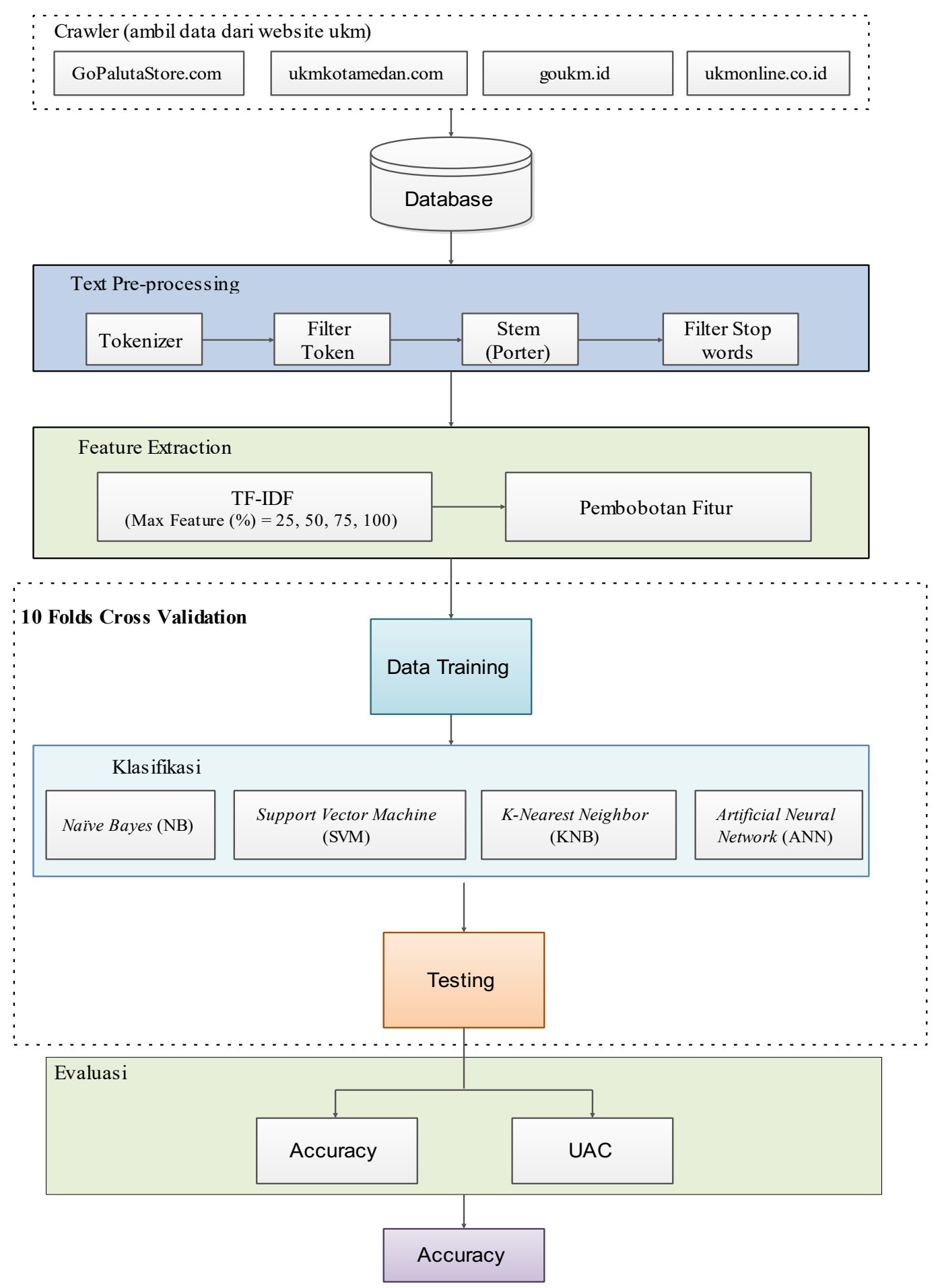

Gambar 1. Kerangka Metode Yang Diusulkan

Cara kerja metode ini adalah mengelompokkan dataset yang ada pada komentar konsumen pada Facebook dan Instagam, berdasarkan komentar pelanggan tersebut dilakukan pelatihan dan pengujian berdasarkan dataset melalui tahapan text pre-pocessing, feature Extraction, 10 folds Cross Validation dan evaluasi. Lalu diproses menggunakan komparasi algoritma Klasifikasi Machine Learning yang terdiri dari Support Vector Machine (SVM), Naïve Bayes (NB), K-Nearsst Neighbor (KNN) dan Artificial Neural Network (ANN) hingga menghasilkan output yang 
diinginkan guna meningkatkan penjualan UMKM dimasa Covid-19.

Tahapan yang dilakukan adalah melakukan klasifikasi komentar pengunjung berdasarkan produk yang ada di Facebook dan Instagam, Kemudian membuat kerangka analisis pengujian. Peneliti mengusulkan komparasi 4 (empat) algoritma klasfiikasi (SMV, NB, KNB dan ANN). Pada Gambar 1 menunjukkan komparasi algoritma klasifikasi yang diusulkan. Sebelum dilakukan komparasi, dataset dilakukan text processing terlebih dahulu. Text processing bertujuan untuk mempersiapkan dokumen teks yang tidak terstruktur menjadi data terstruktur yang siap digunakan untuk proses selanjutnya. Tahapan text processing meliputi:

a. Tokenize merupakan proses untuk memisahmisahkan kata. Potongan kata tersebut disebut dengan token atau term.

b. Filter Token merupakan proses mengambil katakata penting dari hasil token.

c. Stem yaitu proses pengubahan bentuk kata menjadi kata dasar. Metode pengubahan bentuk kata menjadi kata dasar ini menyesuaikan struktur bahasa yang digunakan dalam proses stemming.

d. Filter stopwords adalah proses menghilangkan kata-kata yang sering muncul namun tidak memiliki pengaruh apapun dalam ekstraksi sentimen suatu review. Kata yang termasuk seperti kata penunjuk waktu, kata tanya.

Pada pelatihan dataset, dilakukan klasifikasi yang terdiri dari:

a. K-Fold Cross Validation

K Fold Cross Validation adalah salah satu metode cross validation yang digunakan untuk menghitung akurasi prediksi suatu sistem. Data dibagi menjadi $\mathrm{k}$ segmen yang memiliki rasio yang sama atau hampir sama. Pelatihan terhadap data dan validasi sebanyak $\mathrm{k}$ kali dengan setiap percobaan mengambil satu segmen berbeda sebagai data tes atau validasi dan k-1 segmen lainnya sebagai data latih untuk diambil rata-rata dari hasil tiap iterasi (L. Liu \& Özsu, 2009).

b. Support Vector Machine

Support Vector Machine (SVM) adalah sebuah sistem pembelajaran yang menggunakan ruang hipotesis berupa fungsi-fungsi linear dalah ruang fitur (fitur space) berdimensi tinggi, dilatih dengan algoritma pembelajaran berdasarkan pada teori optimasi dengan mengimplementasikan learning bias yang berasal dari teori pembelajaran statistik (Ulwan, 2016). c. TF-IDF (Term Frequency - Inverse Document Frequency)

Algoritma TF-IDF (Term Frequency - Inverse Document Frequency) adalah salah satu algoritma yang dapat digunakan untuk menganalisa hubungan antara sebuah frase/kalimat dengan sekumpulan dokumen. Inti utama dari algoritma ini adalah melakukan perhitungan nilai TF dan nilai IDF dari sebuah setiap kata kunci terhadap masing-masing dokumen. Nilai TF dihitung dengan rumus $\mathrm{TF}=$ jumlah frekuensi kata terpilih / jumlah kata dan nilai IDF dihitung dengan rumus IDF $=\log$ (jumlah dokumen/jumlah frekuensi kata terpilih). Selanjutnya adalah melakukan perkalian antara nilai TF dan IDF untuk mendapatkan jawaban akhir (Ulwan, 2016).

d. Analisis Sentimen

Klasifikasi sentimen digunakan untuk menyelesaikan masalah klasifikasi dua kelas, positif dan negatif. Data pengujian yang digunakan biasanya adalah ulasan produk secara online. Karena ulasan online memiliki nilai penilaian yang ditetapkan oleh para peneliti. Sebagian besar makalah penelitian tidak menggunakan kelas netral, dengan tujuan agar memudahkan masalah klasifikasi, namun juga tidak jarang peneliti yang menggunakan kelas netral, misalnya penggunaan peringkat bintang tiga sebagai kelas netral (Informatikalogi Team, 2016)

e. Machine Learning

Machine learning adalah suatu area dalam artificial intelligence yang berhubungan dengan penggembangan teknik-teknik yang bisa diprogramkan dan belajar dari data masa lalu. Machine learning sebagai alat analisis dalam data mining (B. Liu, 2012).

\section{Dataset}

Adapun penjualan produk UMKM berasal dari daerah khas kabupaten Nias yang dipasarkan melalui media social, dikelompokkan kedalam empat kategori, yaitu produk kerajinan tangan, produk makanan, barang antik dan produk alat musik.

\section{Kategori Produk Kerajinan Tangan}

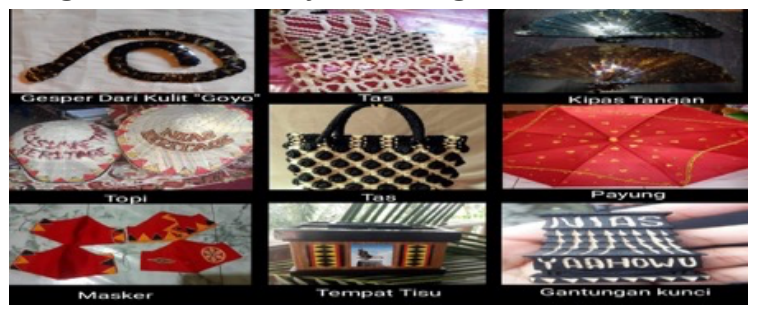

Gambar 2. Kategori Produk Kerajinan Tangan 


\section{Kategori Makanan Produk Khas Nias}

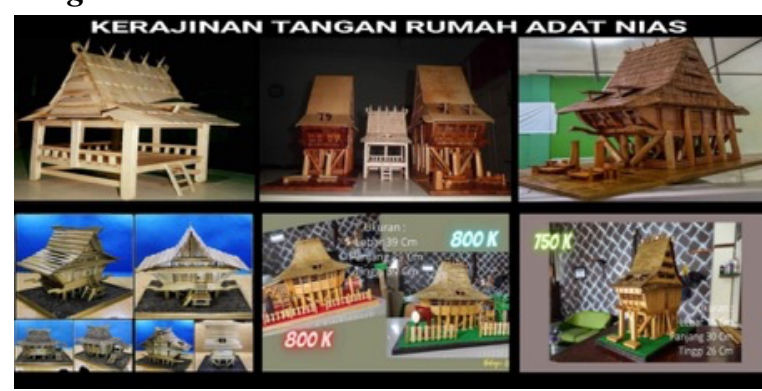

Gambar 3. Kategori Makanan Produk Khas Nias

\section{Kategori Barang Antik Produk Khas Nias}

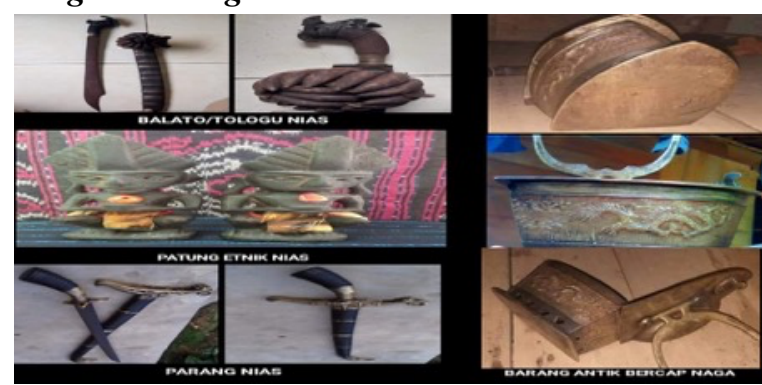

Gambar 4. Kategori Barang Antik Produk Khas Nias

\section{HASIL DAN PEMBAHASAN}

Pada penelitian Komparasi Algoritma Klasifikasi Machine Learning Pada Analisis Sentimen penjualan Produk UMKM Kabupaten Nias, tahapan yang dilakukan adalah melakukan klasifikasi komentar pengujung berdasarkan produk yang ada di Facebook dan Instagram kemudian penulis membuat kerangka analisis pengujian. Peneliti mengusulkan untuk mengkomparasi 4 (empat) algoritma klasfiikasi (SVM, NB, KNN dan ANN). Pengujian dilakukan dengan menggunakan spesifikasi CPU Intel Core i7 $1.8 \mathrm{GHz}$, RAM 16 GB, dan sistem operasi Microsoft Windows 10 Home 64-bit, pada tabel 1 merupakan hasil klasifikasi perbandingan metode yang diusulkan dan gambar 7 Grafik Perbandingan.

Tabel 1. Hasil Perbandingan Klasifikasi

\begin{tabular}{|c|c|r|r|c|c|}
\hline Method & Accuracy & Precision & Recall & $\begin{array}{c}\text { TP } \\
\text { Rate }\end{array}$ & $\begin{array}{c}\text { TN } \\
\text { rate }\end{array}$ \\
\hline NB & 87.00 & 78.00 & 80.00 & 86.00 & 82.00 \\
\hline SVM & 92.00 & 95.00 & 82.00 & 84.00 & 91.00 \\
\hline KNN & 64.00 & 94.00 & 73.00 & 62.00 & 62.00 \\
\hline ANN & 65.00 & 62.00 & 58.00 & 78.00 & 74.00 \\
\hline
\end{tabular}

\section{Kategori Alat Musik Khas Nias}

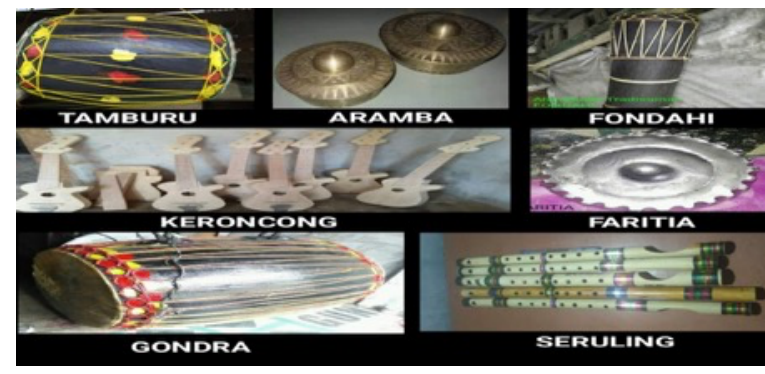

Gambar 5. Kategori Alat Musik Khas Nias

\section{Kategori Pakaian Adat Nias Dan Ornamen Nias}

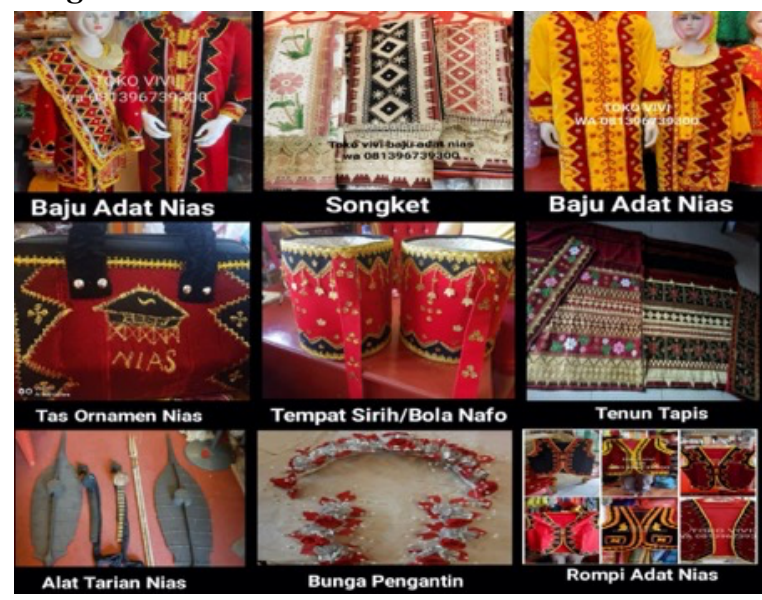

Gambar 6. Kategori Pakaian Adat Nias Dan Ornamen Nias

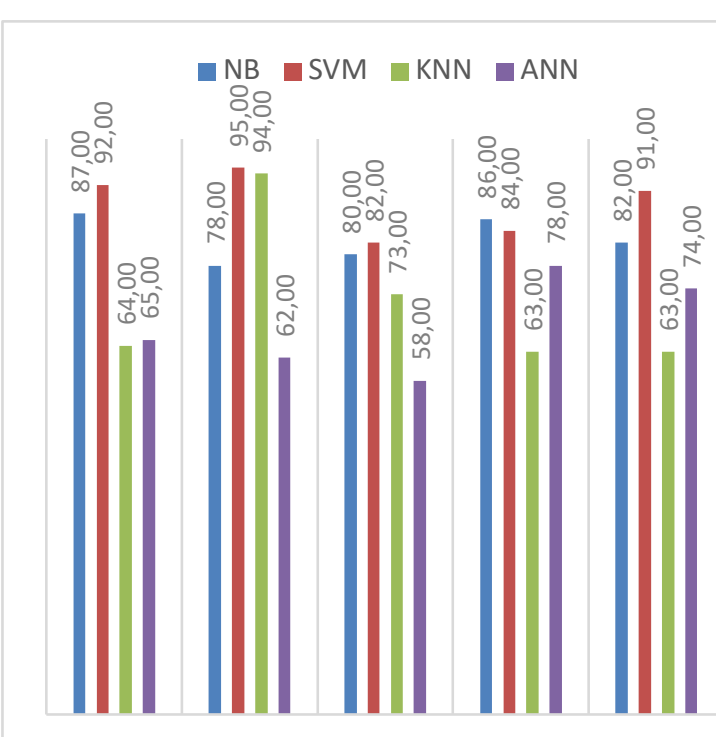

ACCURACPRECISIONRECALL TP RATE TN RATE

Gambar 7. Grafik Komparasi Algoritma Machine Learning

Tabel 2. Hasil Komparasi Algoritma Machine Learning

\begin{tabular}{|c|c|}
\hline Metode & UAC \\
\hline NB & 0.867 \\
\hline SVM & 0.988 \\
\hline KNN & 0.609 \\
\hline ANN & 0.429 \\
\hline
\end{tabular}




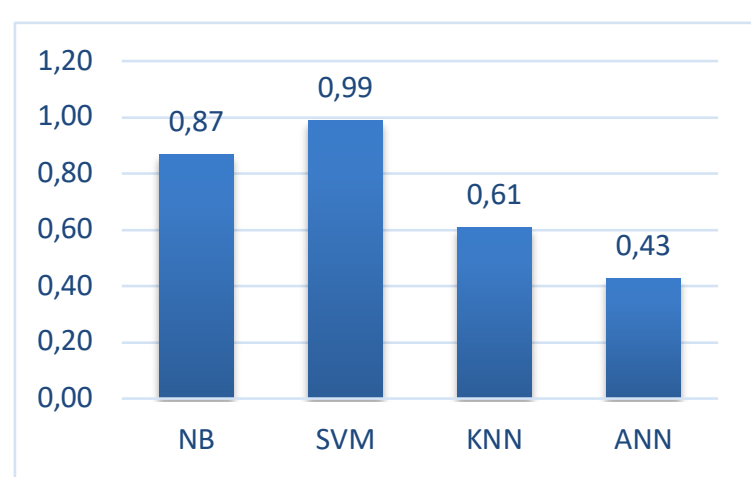

Gambar 8. Grafik UAC Komparasi Algoritma Machine Learning

Adapun hasil yang diperoleh berdasarkan Table 1 merupakan hasil komparasi Klasifikasi algoritma Machine Learning berdasarkan nilai akurasi, presisi, recall, TP rate dan TN rate, dimana metode SVM menghasilkan nilai tertinggi dibandingkan dengan metode lainnya, sedangkan ANN menghasilkan nilai paling rendah. Penerapan metode untuk klasifikasi analisis sentimen memiliki tingkat ketergantungan pada dataset pelatihan dan pengujian. Pada table 2 komparasi algoritma machine Learning dengan nilai Under Are Curve (UAC) pada metode ANN lebih kecil sebesar 0.429 dan metode SVM lebih tinggi sebesar 0.988. Dalam hal ini melalui algoritma SVM dapat dilakukan pengujian dataset yang lebih banyak dengan menambahkan penjualan produk UMKM pada Media Sosial leboh banyak lagi, sehingga dapat memperoleh hasil yang lebih akurat.

\section{KESIMPULAN}

Berdasarkan hasil pengujian komparasi metode Naïve Bayes (NB), Support Vector Machine (SVM), dan K-Nearest Neighbor (KNN), Artificial Neural Network (ANN) untuk klasifikasi analisis sentimen penjualan produk UMKM Kabupaten Nias menghasilkan tingkat akurasi sebesar 96\% dan 0.9 UAC pada metode SVM, namun karena keterbatasan sumber data pelatihan dan pengujian sangat tergantung untuk menghasilkan akurasi yang lebih baik.

\section{DISEMINASI}

Artikel ini telah diseminasikan pada Seminar Nasional Inovasi \& Informatika (SNIIf 2021) yang diselenggarakan oleh Fakultas Ilmu Komputer Universitas Methodist Indonesia pada tanggal $23 \mathrm{Juli}$ 2021.

\section{DAFTAR PUSTAKA}

Admin Dinas Kominfo Sumut. (2020). Pemprov Sumut akan Siapkan Aplikasi Marketplace untuk UMKM.

Https://Diskominfo.Sumutprov.Go.Id/.

Admin Kabupaten Nias. (2020). 4 Daerah kepulauan Nias di Tetapkan sebagai daerah teringgal tahu 2020-2024. Niaskab.Go.Id.

Agustian, W. (2020). 5 Upaya Pemerintah Selamatkan UMKM di Tengah Covid-19. Okezone.Com.

Retrieved from https://economy.okezone.com/read/2020/05/06/ 320/2210013/5-upaya-pemerintah-selamatkanumkm-di-tengah-covid-19

Chen, H. (2012). The impact of comments and recommendation system on online shopper buying behaviour. Journal of Networks, 7(2), 345.

Ernawati, S., \& Wati, R. (2018). Penerapan Algoritma K-Nearest Neighbors Pada Analisis Sentimen Review Agen Travel. Jurnal Khatulistiwa Informatika, 6(1), 64-69. https://doi.org/10.31294/jki.v6i1.3802

Hanggara, S., Akhriza, T. M., \& Husni, M. (2017). Aplikasi Web Untuk Analisis Sentimen Pada Opini Produk Dengan Metode Naive Bayes Classifier. Prosiding Seminar Nasional Inovasi Dan Aplikasi Teknologi Di Industri (SENIATI 2017), A33-1.

Haryanto, D. J., Muflikhah, L., \& Fauzi, M. A. (2018). Analisis sentimen review barang berbahasa Indonesia dengan metode support vector machine dan query expansion. Jurnal Pengembangan Teknologi Informasi Dan Ilmu Komputer, 2(9), 2909-2916.

Indriati, I., \& Ridok, A. (2016). SENTIMENT ANALYSIS FOR REVIEW MOBILE APPLICATIONS USING NEIGHBOR METHOD WEIGHTED K-NEAREST NEIGHBOR (NWKNN). Journal of Enviromental Engineering and Sustainable Technology, 3(1), 23-32. https://doi.org/10.21776/ub.jeest.2016.003.01.4 Informatikalogi Team. (2016). Pembobotan Kata atau Term Weighting TF-IDF.

Liu, B. (2012). Sentiment Analysis and Opinion Mining. California: Morgan \& Claypool Publishers.

Liu, L., \& Özsu, M. T. (2009). Encyclopedia of database systems (6th ed.). Springer.

Lutfi, A. A., Permanasari, A. E., \& Fauziati, S. (2018). Sentiment Analysis in the Sales Review of Indonesian Marketplace by Utilizing Support Vector Machine. Journal of Information Systems Engineering and Business Intelligence, 4(1), 57-64.

Muljono, M., Artanti, D. P., Syukur, A., \& Prihandono, A. (2018). Analisa Sentimen Untuk Penilaian Pelayanan Situs Belanja Online Menggunakan Algoritma Naïve Bayes. 
Konferensi Nasional Sistem Informasi (KNSI) 2018, 165-170.

Nurjanah, W. E., Perdana, R. S., \& Fauzi, M. A.

(2017). Analisis Sentimen Terhadap Tayangan

Televisi Berdasarkan Opini Masyarakat pada

Media Sosial Twitter menggunakan Metode K-

Nearest Neighbor dan Pembobotan Jumlah

Retweet. Jurnal Pengembangan Teknologi

Informasi Dan Ilmu Komputer, 1(12), 1750-

1757.

Rofiqoh, U., Perdana, R. S., \& Fauzi, M. A. (2017).

Analisis sentimen tingkat kepuasan pengguna penyedia layanan telekomunikasi seluler indonesia pada twitter dengan metode Support Vector Machine dan Lexicon Based Features. Jurnal Pengembangan Teknologi Informasi Dan Ilmu Komputer, 1(12), 1725-1732.

Saifinnuha, A. Z. (2015). Penerapan Sentimen Analisis Pada Twitter Berbahasa Indonesia Untuk Mendapatkan Rating Program Televisi Menggunakan Metode Support Vector Machine. Universitas Brawijaya.

Santia, T. (2020). 5 Kebijakan Menkop Atasi Masalah UMKM di Masa Pandemi Corona.

Liputan6.Com. Retrieved from https://www.liputan6.com/bisnis/read/4283318/ 5-kebijakan-menkop-atasi-masalah-umkm-dimasa-pandemi-corona

Siringoringo, R., Jamaluddin, \& Perangin-Angin, R. (2020). Pemodelan Topik Berita Menggunakan Latent Dirichlet Allocation dan K-Means Clustering. Jurnal Informatika Kaputama (JIK), 4(2), 216-222.

Taufik, A. (2018). Komparasi Algoritma Text Mining Untuk Klasifikasi Review Hotel. Jurnal Teknik Komputer, 4(2), 112-118.

Ulwan, M. N. (2016). Pattern Recognition pada Unstructured Data Teks Menggunakan Support Vector Machine dan Association. Universitas Islam Indonesia.

Yennimar, Rizal, R. A., Husein, A. M., \& Harahap, M. (2019). Sentiment analysis for opinion IESM product with recurrent neural network approach based on long short term memory. 2019 International Conference of Computer Science and Information Technology (ICOSNIKOM), 14. https://doi.org/10.1109/ICoSNIKOM48755.201 9.9111516 